\title{
Quality of Chicken Sausage Fortified with Nano-Calcium Duck Eggshell in Different Vacuum Packaging during Storage at $-18^{\circ} \mathrm{C}$
}

\author{
Prayitno AH, Lorenza F, Suparmi, Naafi’yan MH \\ Departement of Animal Science, Politeknik Negeri Jember \\ Jl. Mastrip Po Box 164 Jember - Indonesia \\ E-mail: agushp@polije.ac.id
}

(received 09-09-2022; revised 15-01-2022; accepted 20-01-2022)

\begin{abstract}
ABSTRAK
Prayitno AH, Lorenza F, Suparmi, Naafi'yan MH. 2021. Kualitas sosis ayam yang difortifikasi nano kalsium kerabang telur itik dalam kemasan vakum yang berbeda selama penyimpanan suhu $-18^{\circ} \mathrm{C}$. JITV 26(4):152-157. DOI: http://dx.doi.org/10.14334/jitv.v26i4.2900.

Penelitian ini bertujuan untuk mengetahui pengaruh fortifikasi nano kalsium kerabang telur itik dan jenis kemasan yang berbeda terhadap kualitas sosis ayam. Materi penelitian terdiri dari nano kalsium kerabang telur itik, daging fillet ayam, gula pasir, bawang putih bubuk, garam, lada, tepung tapioka, es batu, minyak, isolate soya protein, sodium tripolifosfat, monosodium glutamat, selongsong kolagen sosis, kemasan polyethylene, nylon, dan retort pouch. Perlakuan fortifikasi nano kalsium kerbang telur yaitu P0 (0\%) dan P1 (0,3\%) dari total adonan. Perlakuan kemasan vakum yaitu K1 (polyethylene), K2 (nylon), dan K3 (retort pouch). Semua sosis ayam dikemas vakum dan disimpan pada suhu $-18^{\circ} \mathrm{C}$ dengan waktu pengamatan 0 dan 14 hari. Parameter yang diuji yaitu kadar air, nilai $\mathrm{pH}$, bilangan peroksida, dan total plate count. Data hasil uji dianalisis dengan analisis variansi rancangan acak lengkap pola faktorial dan jika terdapat perbedaan yang signifikan $(\mathrm{P}<0,05)$ kemudian diuji lanjut dengan uji Duncan's New Multiple Range Test. Sosis yang difortifikasi nano kalsium kerabang telur itik dengan kemasan vakum retort pouch merupakan perlakuan terbaik dengan bilangan peroksida terendah pada umur simpan 14 hari. Sosis yang difortifikasi nano kalsium kerabang telur itik dengan kemasan vakum retort pouch pada umur simpan 14 hari memiliki kadar air $(51,59 \%)$, nilai $\mathrm{pH}(6,83)$, bilangan peroksida $\left(64,64 \mathrm{meq} \mathrm{O}_{2} / \mathrm{kg}\right)$, dan total plate count $\left(3,50 \times 10^{3} \mathrm{cfu} / \mathrm{g}\right)$.
\end{abstract}

Kata Kunci: Sosis ayam, Kerabang Telur itik, Fortifikasi, Nano kalsium, Kemasan vakum

\begin{abstract}
Prayitno AH, Lorenza F, Suparmi, Naafi'yan MH. 2021. Quality of chicken sausage fortified with nano-calcium duck eggshell in different vacuum packaging during storage at $-18^{\circ} \mathrm{C}$. JITV 26(4): 152-157. DOI: http://dx.doi.org/10.14334/jitv.v26i4.2900.

This study aimed to determine the effect of fortification of duck eggshell nano-calcium and different types of packaging on the quality of chicken sausage. The sausage was made of duck eggshell nano-calcium, chicken fillet, sugar, garlic powder, salt, pepper, tapioca, ice, oil, soy protein isolate, sodium tripolyphosphate, monosodium glutamate, collagen casing, polyethylene, nylon, and retort pouch packaging. Treatment for fortification of duck eggshell nano-calcium was P0 (0\%) and P1 (0.3\%) of the total dough. Vacuum packaging treatments were K1 (polyethylene), K2 (nylon), and K3 (retort pouch). All chicken sausages were vacuum-packed and stored at $-18^{\circ} \mathrm{C}$ for 0 and 14 days of observation. Parameters tested were water content, $\mathrm{pH}$ value, peroxide value, and total plate count. Data collected were analyzed by analysis of variance in a completely randomized design with factorial patterns and if there was a significant difference $(\mathrm{P}<0.05)$ then further tested with Duncan's New Multiple Range Test. Sausage fortified with duck eggshell nano-calcium with vacuum retort pouch packaging was the best treatment with the lowest peroxide value at day 14 shelf life. Sausage fortified with nano-calcium duck eggshell with vacuum retort pouch packaging at day 14 shelf life had moisture (51.59\%), $\mathrm{pH}$ value (6.83), peroxide value (64.64 meq $\left.\mathrm{O}_{2} / \mathrm{kg}\right)$, and total plate count $\left(3.50 \times 10^{3} \mathrm{cfu} / \mathrm{g}\right)$.
\end{abstract}

Key Words: Chicken sausage, Duck eggshell, Fortified, Nano-calcium, Vacuum-packaged

\section{INTRODUCTION}

Age and gender are the factors that affect the daily calcium requirement of the human body. Calcium needs of children $600 \mathrm{mg} /$ day, adults $800 \mathrm{mg} /$ day up to 1,000 $\mathrm{mg}$ /day (Justicia et al. 2012). Calcium deficiency in children causes rickets while in adults it can cause osteomalacia and osteoporosis (Deborah et al. 2016).
Sources of calcium in food are obtained from milk, vegetables, and fish. But not all calcium from these foods can be directly utilized by the body because there are factors that can increase or decrease calcium absorption. Milk is recommended as the best source of calcium, but milk is still expensive for some people and some people are lactose intolerant, meaning they cannot digest lactose or the natural sugar found in milk and 
other dairy products. Whereas there are other sources of calcium that have the potential to contain higher calcium when compared to milk, namely eggshells. Eggshells contain 94-97\% calcium carbonate (Nurlaela et al. 2014). Duck eggshells are the second most widely source of calcium produced in Indonesia. Duck eggshells can be increased in economic value and physicochemical properties through the application of nanotechnology into calcium nanoparticles.

The particle size of calcium in duck eggshells can be changed from $13,229 \mathrm{~nm}$ to $347 \mathrm{~nm}$ with high energy ball milling (Prayitno \& Sutirtoadi 2019; Prasetyo \& Prayitno 2021) with a calcium content of around 54.36-59.27\% (Prayitno et al. 2020). The small size of nanoparticles can cause the extract to be easily soluble and have a high absorption efficiency in the intestine due to an increase in surface area, whereas calcium is generally micro-sized calcium. Nanocalcium oxide is one type of metal oxide that has been widely applied as a catalyst (Gopalappa et al. 2012), antibacterial (Roy et al. 2013; Wang et al. 2017), food additives (Prasetyo \& Prayitno 2021), and is able to increase solubility and absorption by the body. Nanosized duck eggshell as a source of natural food calcium is very good as a functional component that can have a positive effect on health.

Prasetyo \& Prayitno (2020) and Prasetyo \& Prayitno (2021) reported that nano-calcium duck eggshell fortified sausages can improve chemical quality (increase protein content, ash, and calcium) and do not change sensory quality to the level of $0.3 \%$. Sausage is a product made from raw meat that is mashed with or without the addition of other food ingredients and permitted food additives and is inserted into sausage casings with or without a cooking process (SNI 2015). One of the functional foods is sausage enriched with eggshell calcium (Astawan 2011). Research on eggshell calcium fortification in sausage products has been carried out and can prevent osteoporosis in humans (Murota et al. 2010).

People's consumption patterns are currently starting to change due to busyness, the demands of life, the Covid-19 pandemic, so they prefer ready-to-cook and ready-to-eat products, one of which is sausage. Sausage products have a large market share in Indonesia. Sausage is classified as a processed meat product that is stored in frozen conditions because it is perishable when stored at room temperature due to microbial contamination. The growth and development of microbes can be prevented through storage and preservation processes (Yusuf et al. 2016). Sausage products are usually packaged before storage to prevent quality degradation. Packaging is a container that is usually used to protect sausage products and maintain the quality of sausages for a certain time. This type of packaging can prevent damage to the product
(Hendrawan et al. 2016). Sausage products can be packaged in polyethylene, nylon, and retort pouch which is thought to be able to maintain quality and longer shelf life without damaging the physical condition and not changing the flavor of the product.

Polyethylene packaging is the most used packaging for packaging sausage products. Polyethylene packaging is easy to obtain, the price is relatively cheap, and has a good ability to protect the product (Moniharapon 2013). Nylon packaging can be used for animal products that are stored at low temperatures and have low permeability to water (Candra \& Sucita 2015). Retort bag packaging materials have evolved from being mostly aluminum foil structures to sophisticated multi-layered packaging, high barrier laminates so that food packaged in retort bags tastes much better than canned products (Shah et al. 2017). The advantages of processed foods packaged in retort bags are more accepted by consumers than foods packaged in glass and metal containers because they are lighter, attractive, and end-use convenient. However, there is no supporting data regarding the use of various types of packaging for chicken sausage products enriched by duck eggshell nano-calcium. Therefore, it is necessary to research to determine the effect of fortification of duck eggshell nano-calcium and different types of packaging on the quality of chicken sausage.

\section{MATERIALS AND METHODS}

\section{Materials}

The material of sausage consisted of chicken fillet, spices, sugar, garlic powder, salt, pepper, tapioca, ice, oil, soy protein isolate (SPI), sodium tripolyphosphate (STPP), monosodium glutamate (MSG), frankfurter, collagen casing, duck eggshell, polyethylene, nylon, and retort pouch packaging.

\section{Methods}

This study consisted of several stages, namely duck eggshell nano-calcium processing, sausage processing, vacuum packaging, storaging, sausage quality analysis, and data analysis.

\section{Duck eggshell nano-calcium processing}

Processing duck eggshell nano-calcium using high energy ball milling (Prasetyo \& Prayitno 2021). Duck eggshells were soaked in hot water for 10 minutes, the eggshell membranes were cleaned, dried at a temperature of $105^{\circ} \mathrm{C}$ for 12 hours, then mashed using a sample mill. Eggshell flour was calcined at a 
temperature of $1,000^{\circ} \mathrm{C}$ for 2 hours and then further processed using high energy ball milling for 60 minutes to produce calcium nanopowder.

\section{Sausage processing}

The formulation of chicken sausage in this study was according to Prasetyo \& Prayitno (2021). The chicken sausage formulation consisted of $50 \%$ chicken fillet, $16.5 \%$ tapioca, $2.5 \%$ soy protein isolate, $10.5 \%$ oil, $1.2 \%$ salt, $0.5 \%$ sodium tripolyphosphate, $1.2 \%$ garlic, $1 \%$ monosodium glutamate, $2 \%$ shallot, $2 \%$ onion, $0.2 \%$ pepper, $0.2 \%$ coriander, $0.2 \%$ nutmeg, $0.5 \%$ sugar, $1 \%$ frankfurter, and $10.5 \%$ ice. Treatment of duck eggshell nano-calcium fortification was $\mathrm{P} 0$ $(0 \%)$ and P1 $(0.3 \%)$ of the total sausage dough. Sausage processing begins with the chicken meat cleaned of connective tissue and then ground using a grinder. The ground chicken and oil are mixed using a meat processor. Then add salt, STPP, MSG, SPI, treatment of duck eggshell nano-calcium $(0.3 \%)$, and half of the ice. All spices are ground, oil, tapioca, and the remaining half of the ice are mixed using a meat processor. Then the sausage mixture is inserted into the sleeve. Raw sausage is then steamed for 60 minutes at a temperature of $60-70^{\circ} \mathrm{C}$. After the cooked sausage was cooled, it was vacuum-packed with either: K1 (polyethylene), K2 (nylon), K3 (retort pouch), and stored at $-18^{\circ} \mathrm{C}$ with an observation time of 0 and 14 days.

\section{Sausage quality analysis}

Quality of chicken sausage tested was moisture, $\mathrm{pH}$ value, peroxide value (AOAC 2019), and total plate count (SNI 2009). Observation time on the quality of chicken sausage was tested on 0 , and 14 days shelf life.

\section{Data analysis}

The test data were analyzed by analysis of variance in a completely randomized design with a factorial pattern and if there was a significant difference $(\mathrm{P}<0.05)$ then further tested with Duncan's New Multiple Range Test (Riadi 2014).

\section{RESULTS AND DISCUSSION}

\section{Moisture}

Moisture of chicken sausage fortified with duck eggshell nano-calcium in different vacuum-packaged during storage at $-18^{\circ} \mathrm{C}$ is presented in Table 1 . The results showed that nano-calcium fortification and different types of packaging was significantly affected
$(\mathrm{P}<0.05)$ moisture of sausages at day 14 shelf life, but different shelf-life did not significantly affect $(\mathrm{P}>0.05)$ moisture of sausages. There was no significant interaction $(\mathrm{P}>0.05)$ between nano-calcium fortification and different types of packaging during storage at $-18^{\circ} \mathrm{C}$ to the moisture of sausages. Sausage moisture in this study ranged from 47.87-51.59\% lower than that of Lengkey et al. (2016) which ranged from 54.70$56.64 \%$. The moisture in this study still meets the standard of moisture of sausage products, which is a maximum of $67 \%$ (SNI 2015).

Results showed that sausages without fortification and with fortification of nanocalcium in polyethylene packaging had the lowest moisture compared to all treatments. The highest moisture of sausages is produced from sausages fortified with nano-calcium in retort pouch packaging, which was around $51.14 \%$. This is in accordance with previous research which showed that eggshell calcium fortification can increase the moisture of processed meat products because it has higher water retention and water holding capacity when compared to meat products that are not fortified eggshells (Prayitno 2014; Suryanto et al. 2014; Prayitno et al. 2016).

Table 1. Moisture (\%) of chicken sausage fortified with nano-calcium duck eggshell in different vacuum packaging during storage at $-18^{\circ} \mathrm{C}$

\begin{tabular}{cccc}
\hline \hline \multirow{2}{*}{ Fortification } & \multirow{2}{*}{$\begin{array}{c}\text { Types of } \\
\text { Packaging }\end{array}$} & \multicolumn{2}{c}{ Shelf Life } \\
\cline { 3 - 4 } & K1 & 49.65 & $47.87^{\mathrm{ab}}$ \\
\hline \multirow{2}{*}{ P0 } & K2 & 49.65 & $49.95^{\mathrm{ab}}$ \\
& K3 & 49.65 & $47.41^{\mathrm{a}}$ \\
& K1 & 50.69 & $48.96^{\mathrm{ab}}$ \\
P1 & K2 & 50.69 & $50.94^{\mathrm{ab}}$ \\
& K3 & 50.69 & $51.59^{\mathrm{b}}$ \\
\hline a-b Different superscripts on the same column showed a significant
\end{tabular}
effect $(\mathrm{P}<0.05)$

\section{Value of pH}

$\mathrm{pH}$ value of chicken sausage fortified with duck eggshell nano-calcium in different vacuum-packaged during storage at $-18^{\circ} \mathrm{C}$ is presented in Table 2 . Results showed that effect of nano-calcium fortification and different types of packaging was significant different $(\mathrm{P}<0.05)$ on $\mathrm{pH}$ value of sausages at day 0 and 14 shelf life. In addition, different shelf life also significantly affected $(\mathrm{P}<0.05) \mathrm{pH}$ value of sausages. There was no significant interaction $(\mathrm{P}>0.05)$ between nano-calcium fortification and different types of packaging during storage at $-18^{\circ} \mathrm{C}$ to the $\mathrm{pH}$ value. 
The $\mathrm{pH}$ value in this study ranged from 6.38-7.19. This $\mathrm{pH}$ value decreased after 14 days of storage from 6.78 to 6.49 . The $\mathrm{pH}$ value was influenced by the presence of duck eggshell nano-calcium. The $\mathrm{pH}$ value was higher than that of not fortified with duck eggshell nano-calcium. The $\mathrm{pH}$ value in this study was still higher than the results of Rahayu et al. (2012) which ranged from 6.00-6.30. A higher $\mathrm{pH}$ value of sausage causes the structure of the meat to open up, giving more space for water molecules.

Results showed that sausage with nano-calcium fortification in nylon packaging had the highest $\mathrm{pH}$ value followed by sausage packaged in retort pouch and polyethylene, respectively, namely 7.10; 7.01, and 7.00. The $\mathrm{pH}$ value is influenced by duck eggshell nanocalcium which contains positively charged ions, namely $\mathrm{Ca}^{2+}$. This is in accordance with previous research which showed that eggshell calcium fortification could increase $\mathrm{pH}$ value of processed meat products than unfortified products (Prayitno 2014; Suryanto et al. 2014; Prayitno et al. 2016).

\section{Peroxide Value}

Peroxide value of chicken sausage fortified with duck eggshell nano-calcium in different vacuumpackaged during storage at $-18^{\circ} \mathrm{C}$ is presented in Table 3 . The results showed that effect of nano-calcium fortification and different types of packaging was significantly different $(\mathrm{P}<0.05)$ on peroxide value of sausages at day 0 and 14 shelf life. In addition, different shelf life also significantly affected $(\mathrm{P}<0.05)$ the peroxide value. There was no significant interaction $(\mathrm{P}>0.05)$ between calcium nano fortification and different types of packaging during storage at $-18^{\circ} \mathrm{C}$ to the peroxide value of sausages.

Table 2. Value of $\mathrm{pH}$ of chicken sausage fortified with nano-calcium duck eggshell in different vacuum packaging during storage at $-18^{\circ} \mathrm{C}$

\begin{tabular}{cccc}
\hline \multirow{2}{*}{ Fortification } & \multirow{2}{*}{$\begin{array}{c}\text { Types of } \\
\text { Packaging }\end{array}$} & \multicolumn{2}{c}{ Shelf Life } \\
\cline { 3 - 4 } & $\mathrm{K} 1$ & $6.38^{\mathrm{aB}}$ & $6.17^{\mathrm{bA}}$ \\
\hline \multirow{2}{*}{ P0 } & $\mathrm{K} 2$ & $6.38^{\mathrm{aB}}$ & $6.07^{\mathrm{aA}}$ \\
& $\mathrm{K} 3$ & $6.38^{\mathrm{aB}}$ & $6.05^{\mathrm{bA}}$ \\
& $\mathrm{K} 1$ & $7.19^{\mathrm{bB}}$ & $6.81^{\mathrm{cA}}$ \\
& $\mathrm{K} 2$ & $7.19^{\mathrm{bB}}$ & $7.01^{\mathrm{dA}}$ \\
& $\mathrm{K} 3$ & $7.19^{\mathrm{bB}}$ & $6.83^{\mathrm{cA}}$ \\
\hline
\end{tabular}

${ }^{\mathrm{a}-\mathrm{d}}$ Different superscripts on the same column showed a significant effect $(\mathrm{P}<0.05) .{ }^{\mathrm{A}-\mathrm{B}}$ Different superscripts on the same row showed a significant effect $(\mathrm{P}<0.05)$
The peroxide value in this study ranged from 34.94 to $88.75 \mathrm{meq} \mathrm{O}_{2} / \mathrm{kg}$. The value of sausages increased after 14 days of storage from 47.42 to $77.45 \mathrm{meq} \mathrm{O}_{2} / \mathrm{kg}$. The rate of increase in sausage peroxide can be slowed down by fortification of duck eggshell nano-calcium and the use of different types of packaging. The peroxide value of sausage fortified with duck eggshell nano-calcium was lower than sausage that was not fortified with duck eggshell nano-calcium. This is because eggshell calcium is known to be used as an absorbent that can reduce the peroxide value in the oil (Fitriana \& Safitri 2015).

Results showed that sausages with nano-calcium fortification in retort pouch packaging had the lowest peroxide value followed by sausages packaged in polyethylene and nylon, respectively $49.79 ; 57.67$, and $60.17 \mathrm{meq} \mathrm{O}_{2} / \mathrm{kg}$. Fortification with duck eggshell nano-calcium as an adsorbent has the main component, namely calcium carbonate which is polar. Polar duck eggshell calcium as an adsorbent can adsorb free fatty acids that have a polar carboxyl end (Fitriana \& Safitri 2015). The use of retort pouch packaging in layers and high barrier lamination (Shah et al. 2017) can also slow down the oxidation rate of sausages so that the peroxide value of sausages is still relatively lower when compared to all treatments.

\section{Total plate count}

Total plate count of chicken sausage fortified with duck eggshell nano-calcium in different vacuumpackaged during storage at $-18^{\circ} \mathrm{C}$ is presented in Table 4. The results showed that effect of nano-calcium fortification and different types of packaging was

Table 3. Peroxide value (meq $\mathrm{O}_{2} / \mathrm{kg}$ ) of chicken sausage fortified with nano-calcium duck eggshell in different vacuum packaging during storage at $-18^{\circ} \mathrm{C}$

\begin{tabular}{cccc}
\hline \hline \multirow{2}{*}{ Fortification } & \multirow{2}{*}{$\begin{array}{c}\text { Types of } \\
\text { Packaging }\end{array}$} & \multicolumn{2}{c}{ Shelf Life } \\
\cline { 3 - 4 } & K1 & $59.91^{\mathrm{b}}$ & $75.52^{\mathrm{abc}}$ \\
\hline \multirow{2}{*}{ P0 } & K2 & $59.91^{\mathrm{bA}}$ & $88.75^{\mathrm{dB}}$ \\
& K3 & $59.91^{\mathrm{bA}}$ & $69.97^{\mathrm{abB}}$ \\
& K1 & $34.94^{\mathrm{aA}}$ & $80.41^{\mathrm{bcdB}}$ \\
& K2 & $34.94^{\mathrm{aA}}$ & $85.40^{\mathrm{cdB}}$ \\
& K3 & $34.94^{\mathrm{aA}}$ & $64.64^{\mathrm{aB}}$ \\
\hline
\end{tabular}

${ }^{\mathrm{a}-\mathrm{d}}$ Different superscripts on the same column showed a significant effect $(\mathrm{P}<0.05) .{ }^{\mathrm{A}-\mathrm{B}}$ Different superscripts on the same row showed a significant effect $(\mathrm{P}<0.05)$ 
Table 4. Total plate count (cfu/g) of chicken sausage fortified with nano-calcium duck eggshell in different vacuum packaging during storage at $-18^{\circ} \mathrm{C}$

\begin{tabular}{cccc}
\hline \multirow{2}{*}{ Fortification } & \multirow{2}{*}{$\begin{array}{c}\text { Types of } \\
\text { Packaging }\end{array}$} & \multicolumn{2}{c}{ Shelf Life } \\
\cline { 3 - 4 } & $\mathrm{K} 1$ & $2.50 \times 10^{3 \mathrm{~A}}$ & $5.90 \times 10^{3 \mathrm{~dB}}$ \\
\hline \multirow{2}{*}{ P0 } & $\mathrm{K} 2$ & $2.50 \times 10^{3 \mathrm{~A}}$ & $6.10 \times 10^{3 \mathrm{~dB}}$ \\
& $\mathrm{~K} 3$ & $2.50 \times 10^{3}$ & $3.60 \times 10^{3 \mathrm{c}}$ \\
& $\mathrm{K} 1$ & $2.40 \times 10^{3}$ & $2.30 \times 10^{3 \mathrm{~b}}$ \\
$\mathrm{P} 1$ & $\mathrm{~K} 2$ & $2.40 \times 10^{3}$ & $1.40 \times 10^{3 \mathrm{a}}$ \\
& $\mathrm{K} 3$ & $2.40 \times 10^{3}$ & $3.50 \times 10^{3 \mathrm{c}}$ \\
\hline
\end{tabular}

${ }^{\mathrm{a}-\mathrm{d}}$ Different superscripts on the same column showed a significant effect $(\mathrm{P}<0.05) .{ }^{\mathrm{A}-\mathrm{B}}$ Different superscripts on the same row showed a significant effect $(\mathrm{P}<0.05)$

significantly differnt $(\mathrm{P}<0.05)$ on the total plate count of sausages at day 0 and 14 shelf life.

In addition, different shelf life significantly affected $(\mathrm{P}<0.05)$ total plate count of sausages. There was no significant interaction $(\mathrm{P}>0.05)$ between nano-calcium fortification and different types of packaging during storage at $-18^{\circ} \mathrm{C}$ to the total plate count of sausages.

The total plate count in this study ranged from 1.40 $\times 10^{3}-6.10 \times 10^{3} \mathrm{cfu} / \mathrm{g}$. The total plate count increased after 14 days of storage from $2.45 \times 10^{3}$ to $3.80 \times 10^{3}$. The total plate count could be slowed down by fortifying duck eggshell nano-calcium and the use of different types of packaging. The total plate count of fortified sausage was lower than that unfortified. This is because eggshell nano-calcium is known to be used as an antibacterial agent (Roy et al. 2013) so that it can slow down bacterial growth during storage.

Results showed that sausages with nano-calcium fortification in nylon packaging had the lowest total plate count, followed by sausages packaged in polyethylene and retort pouch, respectively $1.90 \times 10^{3}$; $2.35 \times 10^{3}$; and $2.95 \times 10^{3} \mathrm{cfu} / \mathrm{g}$. The total plate count in this study still meets the standard, which is a maximum of $1 \times 10^{5} \mathrm{cfu} / \mathrm{g}$ (SNI 2015). Fortification of duck eggshell nano-calcium as an antibacterial has the main component, namely calcium oxide $(\mathrm{CaO})$. Nanoparticles have broad-spectrum antimicrobial properties that significantly inhibit the growth and reproduction of bacteria (Wang et al. 2017). In addition, metal oxide compounds in the nanoscale can denature microbial cell walls until they are damaged so that the microbial cells die (Sharmila et al. 2018).

\section{CONCLUSION}

Sausage fortified with duck eggshell nano-calcium with vacuum retort pouch packaging was the best treatment with the lowest peroxide value at day 14 shelf life. Sausage fortified with nano-calcium duck eggshell with vacuum retort pouch packaging at day 14 shelf life had moisture $(51.59 \%), \mathrm{pH}$ value (6.83), peroxide value $\left(64.64 \mathrm{meq} \mathrm{O}_{2} / \mathrm{kg}\right)$, and total plate count $\left(3.50 \times 10^{3}\right.$ $\mathrm{cfu} / \mathrm{g})$.

\section{ACKNOWLEDGEMENT}

We would like to thank the Directorate General of Vocational Education, Ministry of Education, Culture, Research, and Technology for funding this research through the 2021 Vocational PKM funding.

\section{REFERENCES}

[AOAC] Association of Official Analytical Chemists. 2019. Official Methods of Analysis of the Association of Analytical Chemists. $21^{\text {th }}$ ed. Washington DC (USA): Association of Official Analytical Chemist.

Astawan M. 2011. Pangan Fungsional Untuk Kesehatan Yang Optimal. Jakarta (Indones): Kompas.

Candra RM, Sucita D. 2015. Sistem pakar penentuan jenis plastik berdasarkan sifat plastik terhadap makanan yang akan dikemas menggunakan metode certainty factor (Studi Kasus: CV. Minapack Pekanbaru). J Ilm Tek Inf. 1:77-84.

Deborah T, Afrianto E, Pratama RI. 2016. Fortifikasi tepung tulang Julung-julung sebagai sumber kalsium terhadap tingkat kesukaan kerupuk. J Perikan Kelaut. 7:48-53.

Fitriana, Safitri E. 2015. Pemanfaatan cangkang telur ayam sebagai adsorben untuk meningkatkan kualitas minyak jelantah. Konversi. 4:12-16.

Gopalappa H, Yogendra K, Mahadevan KM, Madhusudhana N. 2012. A comparative study on the solar photocatalytic degradation of Brilliant Red azo dye by $\mathrm{CaO}$ and $\mathrm{CaMgO}_{2}$ nanoparticles. Int J Sci Res. 1:91-95. DOI:10.13140/RG.2.2.24749.95204.

Hendrawan Y, Ahmad AM, Djoyowasito G, Marantika ME. 2016. Pengkajian beras pecah kulit (brown rice) dalam kemasan vakum (vacuum packaging) berdasarkan ketebalan plastik kemasan jenis nylon. J Keteknikan Pertan Trop dan Biosist. 4:250-261.

Justicia A, Liviawaty E, Hamdani H. 2012. Fortifikasi Tepung Tulang Nila Merah Sebagai Sumber Kalsium Terhadap Tingkat Kesukaan Roti Tawar. J Perikan Kelaut. 3:1727.

Lengkey HAW, Sembor SM, Garnida D, Edianingsih P, Nanah N, Balia RL. 2016. Pengaruh pemberian margarin terhadap sifat fisiko kimiawi dan sensoris sosis ayam petelur afkir. AGRITECH. 36:279-285. DOI: 10.22146/agritech.16590.

Moniharapon A. 2013. Pengaruh kemasan plastik terhadap mutu sosis ikan gulamah (Argyrosomus amoyensis) selama penyimpanan dingin. Maj BIAM. 9:30-39. 
Murota I, Baba T, Shimada M, Sato N. 2010. Safety evaluation of excessive intake of calcium-fortified fish sausage to prevent osteoporosis in humans. J Japanese Soc Food Sci Technol. 57:163-170. DOI:10.3136/nskkk.57.163.

Nurlaela A, Dewi SU, Dahlan K, Soejoko DS. 2014. Pemanfaatan limbah cangkang telur ayam dan bebek sebagai sumber kalsium untuk sintesis mineral tulang. J Pendidik Fis Indones. 10:81-85.

Prasetyo B, Prayitno AH. 2020. Aplikasi Nano Kalsium Alami Kerabang Telur Pada Sosis dan Potensinya Sebagai Pangan Fungsional. Jember.

Prasetyo B, Prayitno AH. 2021. The sensory characteristics of fortified beef sausage with duck eggshell. In: 3rd Int Conf Food Agric. Jember: IOP Conference Series: Earth and Environmental Science; p. 1-6.

Prayitno A, Prasetyo B, Sutirtoadi A. 2020. Synthesis and characteristics of nano calcium oxide from duck eggshells by precipitation method. IOP Conf Ser Earth Environ Sci. 411:1-6. DOI: 10.1088/17551315/411/1/012033.

Prayitno AH. 2014. Karakteristik Bakso dengan Fortifikasi Nanopartikel Kalsium Laktat Kerabang Telur. Yogyakarta (Indones): Universitas Gadjah Mada.

Prayitno AH, Suryanto E, Rusman. 2016. Pengaruh fortifikasi nanopartikel kalsium laktat kerabang telur terhadap sifat kimia dan fisik bakso ayam. Bul Peternak. 40:40-47.

Prayitno AH, Sutirtoadi A. 2019. Karakteristik Nano Kalsium Alami Berbagai Jenis Kerabang Unggas. Jember (Indones): Politeknik Negeri Jember.

Rahayu D, Suharyanto S, Warnoto W. 2012. Karakteristik fisik dan organoleptik sosis daging sapi disubstitusi daging itik talang benih (Anas plathyryncos). J Sain Peternak Indones. 7:93-100.

Riadi E. 2014. Metode Statistika: Parametrik \& NonParametrik. Tangerang (Indones): Pustaka Mandiri.

Roy A, Gauri SS, Bhattacharya M, Bhattacharya J. 2013. Antimicrobial activity of $\mathrm{CaO}$ nanoparticles. J Biomed Nanotechnol. 9:1570-1578. DOI: 10.1166/jbn.2013.1681.

Shah MA, Bosco SJD, Mir SA, Sunooj KV. 2017. Evaluation of shelf life of retort pouch packaged Rogan josh, a traditional meat curry of Kashmir, India. Food Packag Shelf Life. 12:76-82. DOI: 10.1016/j.fps1.2017.04.001.

Sharmila G, Sakthi Pradeep R, Sandiya K, Santhiya S, Muthukumaran C, Jeyanthi J, Manoj Kumar N, Thirumarimurugan M. 2018. Biogenic synthesis of $\mathrm{CuO}$ nanoparticles using Bauhinia tomentosa leaves extract: Characterization and its antibacterial application. J Mol Struct. 1165:288-292. DOI: 10.1016/j.molstruc.2018.04.011.

[SNI] Standar Nasional Indonesia. 2009. Batas Maksimum Cemaran Mikroba dalam Pangan. Jakarta (Indones): Badan Standardisasi Nasional.

[SNI] Standar Nasional Indonesia. 2015. Sosis Daging. Jakarta (Indones): Badan Standardisasi Nasional.

Suryanto E, Setiyono, Rusman, Prayitno AH. 2014. Chemical composition, cooking, physical and sensorial properties of chicken meatball fortified with eggshell calcium powder. In: XIVth Eur Poult Conf. Stavanger: World's Poultry Science Association; p. 1-3.

Wang L, Hu C, Shao L. 2017. The antimicrobial activity of nanoparticles: Present situation and prospects for the future. Int J Nanomedicine. 12:1227-1249.

Yusuf M, Wihansah RRS, Arifin M, Oktaviana AY, Rifkhan, Negara JK, Sio AK. 2016. Kualitas fisik, mikrobiologi dan organoleptik sosis ayam komersil yang beredar di tempat berbeda di Bogor. J Ilmu Produksi dan Teknol Has Peternak. 4:296-299. 